\title{
THE INFLUENCE OF LEADERSHIP, MOTIVATION, AND WORKING ENVIRONMENT ON EMPLOYEE PERFORMANCE IN AGRICULTURE DEPARTMENT OF BOALEMO DISTRICT, GORONTALO PROVINCE
}

\author{
Maman Musa $^{1)}$ and Susillawati Abdullah ${ }^{2)}$ \\ 1,2,) Bina Mandiri University Gorontalo \\ E-mail: maman.musa@ubmg.ac.id
}

\begin{abstract}
The research had purposed to analyze the influence of Leadership, Motivation and Work Environment toward Employees Performance and to determine the variable that had dominant influence on imployees Performance on Department of Agriculture in Boalemo Regency, Gorontalo Province. The research had been done through survey opproach, the sample of research were the employees on Department of Agriculture in Boalemo Regency, GorontaloProvince and the amount about 50 people.

The data collected by questioner's deployment and documentation. Analyzing tool used are validity test, reliability test, and test of classic assumption,multiple linier regression, $t$ test and coefficient determination (R), then the data was processed use the SPSS.

Result of research shows that partially work environment had negative and insignificant influence on employee's performance, while leadership and motivation positively and significant had influence toward imployees performence on Department of Agriculture in Boalemo Regency, Gorontalo Province.
\end{abstract}

Keywords: leadership, motivation, work environment, performance

\section{INTRODUCTION}

To create high performance, it is necessary to increase optimal work and be able to utilize the potential of human resources owned by employees to achieve organizational goals, so that it will make a positive contribution to organizational development. Organizations need to pay attention to various factors that can affect employee performance. Factors that affect employee performance include leadership, motivation and employee work environment [1].

The Boalemo Regency Agriculture Office, Gorontalo Province, is a government agency engaged in an effort to increase community interest in farming and is unceasingly providing services to the community in agricultural issues, such as providing agricultural seeds, services in the field of animal husbandry, and other agricultural program programs.

However, the fact that was encountered by researchers at the initial observation stage at the research location, at the Agriculture Office of Boalemo Regency, Gorontalo Province, there is a phenomenon where there are several employees who work at the agency having a classified performance that is less. Judging from several symptoms in the implementation of employee duties, namely (1) the enthusiasm and morale of employees are still relatively low which causes some employees to often procrastinate their work, so that the achievement of main tasks cannot be achieved properly. (2) there are still

Submit: Oct. $16^{\text {th }}, 2020$

Accepted: Dec. $5^{\text {th }}, 2020$

Published: Dec. $17^{\text {th }}, 2020$

Journal of Economics, Business and Administration (JEBA) — E-ISSN: 2746-1688 43 
The Influence of Leadership, Motivation, and Working Environment on Employee Performance in Agriculture Department of Boalemo District, Gorontalo Province

employees who often don't come to work or skip work, causing work to be neglected or delayed. (3) employees who do not understand the work process technically are still found, resulting in errors and delays in the work process.

This is due, among others, to the lack of a leadership role in guiding and directing employees and the lack of firm leadership in imposing sanctions on violations committed by employees. In addition, researchers assess that the performance achieved is not optimal because some employees feel less attention from the leadership, the leadership is felt to be less able to influence and motivate employees to work better. Likewise, with the work environment, especially in creating a harmonious work atmosphere. By creating a work environment that matches the expectations of employees, it will make them feel comfortable at work. Therefore, the factors of leadership, motivation and work environment will be factors that can improve employee performance in the organization.

Leadership is the ability to direct followers to work together with confidence and diligently carry out the tasks assigned by their leader [19]. Lack of a leadership role in creating harmonious communication and providing employee coaching, will lead to low employee performance levels. This means that a successful leader is a leader who is able to become a role model for his subordinates by providing motivation and creating a work environment that can spur growth and development of employee performance.

The leader is a symbol of role models, drivers and influences who can direct various activities and resources to achieve their goals. The leadership duties are:

1. Encourage, namely being warm, friendly and accepting of people

2. Expressing feelings, namely the act of expressing feelings about work and group cohesiveness, such as satisfaction, pleasure, pride and sharing a feeling with the people they lead when experiencing difficulties, failures and so on.

3. Reconciling, namely the act of finding and reconciling different opinions and bringing down people who are arguing with one another.

4. Succumbing, namely the ability to change and adjust their own opinions and feelings with the opinions and feelings of the people they lead.

5. Streamlining, namely the willingness to help facilitate the participation of members in the group, so that all voluntarily contribute and express their ideas.

6. Installing rules, namely the act of providing rules and regulations that help group life

Hypothesis 1: Leadership has a significant effect on employee performance.

Motivation will affect individual attitudes and behavior at work, so that employee performance is also influenced by motivational factors. motivation is trying so that someone can finish a job with enthusiasm because he wants to do it [19]. If someone is motivated, they will make positive choices to do something because they understand that this action has meaning for them.

Abraham Maslow argued that basically all humans have basic needs and show it in five levels which form a pyramid, people start from the lowest level of encouragement. The five levels of need are as follows:

a. Physiological needs (hunger, thirst, etc.)

b. Need for security (feeling safe and protected, away from harm)

c. The need for love and belonging (affiliation with others, being accepted, belonging)

d. Need for appreciation (achievement, 
potential and getting support and recognition)

e. Self-actualization needs (getting selfsatisfaction and realizing its potential) [4].

Hypothesis 2: Motivation has significant effect on employyee performance

Apart from motivation, another factor that also affects employee performance is the work environment. The work environment is one of the factors that affect employees in doing their jobs [3]. Organizational environmental factors are very supportive for individuals in achieving their work performance [10]. A pleasant work environment, such as clean office conditions, adequate lighting, adequate ventilation, harmonious relations between employees, good leadership, etc., will lead to feelings of satisfaction in employees, so that employees will feel at home and enthusiastic in completing work. Broadly speaking, the type of work environment is divided into 2 , namely the physical work environment and the nonphysical work environment [16]. Included in the physical work environment are:

1. An environment that is directly related to employees. Such as chairs, tables, and so on.

2. General environment is the work environment that affects human conditions, for example temperature, humidity, air circulation, lighting, noise, vibration, unpleasant odors, color, and so on.

\section{Leadership}

Leadership is a very important process in all organizational beats, because the success or failure of an organization will be determined by the leadership process. Leadership is a science that studies comprehensively on how to direct, influence and supervise others to carry out tasks in accordance with planned orders [2]. Leadership can be defined as the ability to direct followers to work together with confidence and be diligent in carrying out the tasks assigned by their leader [19]. Leadership is the ability to influence a group towards the achievement of goals [2]. Leadership is a way for someone to lead to influence their subordinates to be willing to work together productively to achieve organizational goals [5].

The task of a leader in an organization is very important in order to achieve the goals that have been previously set. The leader is a symbol of role models, drivers and influences who can direct various activities and resources to achieve their goals. Leadership tasks related to group cohesiveness, namely:

1. Encourage, namely being warm, friendly and accepting of people

2. Expressing feelings, namely the act of expressing feelings about work and group cohesiveness, such as satisfaction, pleasure, pride and sharing with the people they lead when experiencing difficulties, failures and so on.

3. Reconciling, which is the act of bringing together and reconciling different opinions and bringing down people who are arguing with one another.

4. Succumbing, namely the ability to change and adjust their own opinions and feelings to the opinions and feelings of the people they lead.

5. Streamlining, namely the willingness to help facilitate the participation of members in the group, so that all sincerely contribute and express their ideas.

6. Installing rules, namely the act of conveying rules and regulations that help group life

A person can occupy a leadership position due to the following factors:

1. Appointment and determination from superiors, 
The Influence of Leadership, Motivation, and Working Environment on Employee Performance in Agriculture Department of Boalemo District, Gorontalo Province

2. Because of the inheritance of the position that lasts from generation to generation

3. Because it was chosen by his followers and supporters

4. Due to unofficial recognition from subordinates

5. Because of its advantages it has several personal qualities

6. Because of the demands of the situation, condition, or the needs of the times [7].

The main characteristics that must be

possessed by a leader are:

1. Intelligence (Intelligence), Research in general shows that a leader has a higher level of intelligence than his followers, but not very different.

2. Maturity, Social and Broad Social Relations (Social Maturity and Breadht) Leaders tend to have stable emotions and are mature or mature, and have broad activities and concerns.

3. Self-motivation and drive for achievement Leaders have relatively high motivation and drive for achievement, they work harder for intrinsic value.

4. Human relations attitudes, a successful leader will recognize the self-esteem and dignity of his followers, have high attention and are oriented towards his subordinates [13].

Based on the description above, it can be concluded that a leader must have a higher level of intelligence than his subordinates and have high motivation and drive for achievement as well. Besides that, to see the leadership style of a leader can be seen through indicators.

An effective leader is someone who is able to perform two important functions, namely:

1. Task function. Related to something that must be done to choose and achieve goals rationally, these tasks include creating activities, seeking information, providing information, providing explanation, coordinating, summarizing, testing feasibility, evaluating and diagnosing.

2. Maintenance function. Relates to emotional gratification necessary to develop and maintain a group, society or organization's existence. Some of these functions include encouraging enthusiasm, setting standards, following, expressing feelings, creating harmony and reducing tension [18].

Between the leader and the people, they lead have a relationship that will appear in a pattern of the leadership process. The relationship process between someone who leads with someone who is being led will also appear in the person of a leader. In each reality, the leader in carrying out the leadership process, there is a difference between one leader and another. There are five types of leadership, namely:

1. Democratic type. Type who is humanoriented and provides guidance to followers,

2. Paternalistic type. Acting to protect subordinates as a loving father or mother,

3. Militaristic type. This type uses a lot of command systems, a command system from superior to subordinate and is tough, very authoritarian, wants subordinates to always obey, full of formalities,

4. Autocratic type. This type is based on power and coercion which absolutely must be obeyed,

5. Type of laizzes faire. This type allows the subordinates to do their own thing, all the work and responsibilities are carried out by the subordinates [2].

Three types of leaders from the five types proposed by Siagian. These types of leaders are:

1. Charismatic. The type who has the power of energy, a tremendous attraction that will follow by his followers, 
The Influence of Leadership, Motivation, and Working Environment on Employee Performance in Agriculture Department of Boalemo District, Gorontalo Province

2. Popularity. This type is able to become a leader of the people, because he adheres to the values of traditional society,

3. Administrative. Is a leader who is able to carry out administrative tasks effectively [2].

Every leader basically has a different behavior in leading his followers, the behavior of these leaders is called a leadership style. Style means attitude, movement, behavior, beautiful attitude, good gestures, strength, ability to do good. And leadership style is behavior and strategy, as a result of a combination of philosophy, skills, traits, attitudes, which are often applied by a leader when he tries to influence the performance of his subordinates. The leadership style has three basic patterns, namely those that emphasize the implementation of tasks, those that emphasize cooperative relationships, and those that emphasize the results that can be achieved. So that the most appropriate leadership style is a style that can maximize productivity, job satisfaction, growth, and easily adapt to all situations.

Leadership styles are a way for leaders to influence others or their subordinates in such a way that that person is willing to do the will of the leader to achieve organizational goals even though personally this may not be liked [9]. A manager's leadership style will have a direct effect on the effectiveness of the work group. The work group in the company is a work grouping in the form of a work unit and each work unit is led by a manager. The manager's style of managing human resources in a work unit will have an effect on improving the performance of the unit, which in turn will affect the overall performance of the company.

Leadership style is a way that leaders interact with their subordinates [21]. Another opinion that leadership style is the norm of behavior used by a person when that person tries to influence the behavior of others as he sees it [20].

Based on the description above, it can be concluded that leadership style is a behavior that a leader uses to try to influence employee behavior as desired and to achieve company goals.

There are four styles of leadership, namely:

1. Instructive leadership style. Characterized by one-way communication. The leader defines the role of followers and lets them know what, how, and where to carry out various tasks. Problem-solving and decision-making initiatives are announced, and their implementation is closely monitored by the leader,

2. Consultative leadership style. Characterized by two-way communication. The leader still provides a lot of direction and still makes almost the same decisions, but this is followed by supportive behavior and trying to hear how followers feel about the decisions made and about their ideas and suggestions,

3. Participatory leadership style. This style puts the position of control over problem solving and decision making held alternately. Two-way communication is enhanced, and the leader's role is to actively listen. The responsibility for problem solving and decision-making rests largely with the followers,

4. Delegation leadership style. It is the low level of direction carried out by a leader, because a leader discusses problems together with subordinates so that an agreement is recorded regarding the definition of the problem which is then delegated as a whole to the subordinates. Leaders provide ample opportunities for subordinates to carry out their own performances because they have the ability and confidence to 
The Influence of Leadership, Motivation, and Working Environment on Employee Performance in Agriculture Department of Boalemo District, Gorontalo Province

take responsibility for directing their own behavior [1].

\section{Work motivation}

Motivation in management is shown in human resources in general and subordinates in particular. Motivation questions how to direct the power and potential of subordinates so that they are willing to work together productively to achieve and achieve predetermined goals. The importance of motivation because it causes, channels, and supports human behavior, so that they are willing to work hard and enthusiastically to achieve optimal results.

The role of humans in achieving work goals is very important in achieving organizational goals. To move people to fit what the organization wants, it must be understood that human motivation to work in an organization, because this motivation determines people's behavior to work or in other words, behavior is the simplest reflection of motivation.

The term motivation, in everyday life, has a variety of meanings related to individual behavior and organizational behavior. However, whatever the meaning is, motivation is an important element in humans, which plays a role in realizing success in human business or work. The main basis for implementing motivation by a leader is knowledge and attention to human behavior as a determining factor for organizational success.

The term motivation comes from the Latin word "movere" which means to push or move. Motivation questions how to direct the power and potential to work to achieve the specified goals [5]. Basically, a person works because he wants to fulfill his life's needs. The urge to desire in a person is different from that of another person so that human behavior tends to vary at work. According to Vroom [12], motivation refers to a process of influencing individual choices for various forms of desired activity. Motivation is the provision of the driving force that creates the excitement of a person's work, so that they are willing to cooperate, work effectively and are integrated with all their efforts to achieve satisfaction [6].

Referring to the views of some of the experts above, it can be concluded that motivation is a psychological factor that shows an individual's interest in work, a sense of satisfaction and being responsible for the work being done. Motivation is very decisive for the achievement of a goal. So that leaders must be able to foster the highest possible work motivation for employees.

Motivation arises because of the need to achieve a goal. Motivation theories [4], namely:

1. Maslow's Hierarchy of Needs Theory, Abraham Maslow argued that basically all humans have basic needs and show it in five levels that form a pyramid, people start from the lowest level of encouragement. The five levels of need are as follows:

a. Physiological needs (hunger, thirst, etc.),

b. Need for security (feeling safe and protected, away from harm),

c. The need for love and belonging (affiliation with others, being accepted, belonging),

d. Need for appreciation (achievement, potential and get support and recognition),

e. Self-actualization needs (getting self-satisfaction and realizing its potential)

2. Theory $X$ and $Y$, this theory was put forward by Mc. Gregor who argues about two human views, namely theory $\mathrm{X}$ (negative) and theory $\mathrm{Y}$ (positive), according to theory $\mathrm{X}$ there are four controls that are held by managers, namely:

a. Employees are inherently ingrained in disliking work, 
The Influence of Leadership, Motivation, and Working Environment on Employee Performance in Agriculture Department of Boalemo District, Gorontalo Province

b. Employees who do not like their work should be watched or threatened with penalties for achieving goals,

c. Employees will avoid responsibility,

d. Most employees put security above all factors related to work.

Contrast this with the negative view of human nature in the four theories of Y, namely:

a. Employees can view cooperation appropriately as rest and play,

b. People will exercise self-direction and self-control if they commit to goals,

c. The average person will accept responsibility,

d. Ability to take innovative decisions.

3. Three Needs Theory (three needs theory), This theory was put forward by Mc. Clelland, who said that there are three important things that human needs, namely:

a. Need for achievement (need for achievement)

b. Need for affiliation (the need for social relationships/almost the same as Maslow's social need)

c. Need for power (need for strength)

4. The ERG theory by Alderfer, Aldelfer argues that there are three categories of needs, namely:

1. Existence includes physiological needs such as hunger, thirst, sex, material needs, and a pleasant work environment,

2. Relatedness (relating) includes relationships with people who are important to us, such as family members, friends, and supervisors at work.

3. Growth (growth) includes our desire to be productive and creative to the best of our ability.

Aldefer argues that when the need for existence is not met, the influence may be strong, but that other categories of needs may still be important in directing behavior towards attaining goals. Even though a need is met, the need can continue as a powerful influence in the decision.

5. Two Factor Theory, the theory developed by Hersberg is known as the "Two-Factor Model" of motivation, namely motivational factors and factors hygiene or maintenance. According to this theory, what is meant by motivational factors are things that encourage achievement which are intrinsic, which means that they originate in a person. Meanwhile, what is meant by maintenance factors are factors that are extrinsic in nature, which means that they originate from outside the self that also determine a person's behavior in his life. According to Hezberg, which is classified as a motivational factor, among others, are work, success achieved, growth opportunities, advancement in career and recognition of others. While the factorshygiene or maintenance includes a person's status in the organization, the relationship of an individual with his superiors, with his colleagues, supervisory techniques applied by supervisors, organizational policies, administrative systems in the organization, working conditions and the applicable reward system.

6. Vroom's Motivation Theory, Vroom's theory of cognitive theory of motivation explaining why a person will not do something he believes he cannot do, even if the result of the job is desired. According to Vroom, the level of a person's motivation can be determined by three components, namely:

a. Expectations (expectations) of success on a task

b. Instrumentalist, namely an assessment of what will happen if 
successful in carrying out a task (the success of the task to get a certain outcome)

c. Valence, which is a response to outcomes such as positive, neutral, or negative feelings. Motivation will be high if the effort is to produce something that exceeds expectations, and motivation will be low if the effort is less than expected considering that every individual in the company comes from a variety of different backgrounds, it will be very important for the company to see the needs and expectations of its employees. Talents and skills, and the employee's plans for the future. If the company can find out these things, it will be easier to get employees in the most appropriate positions so that it will further increase motivation for the employees themselves.

\section{Work Environment}

The work environment is the whole of the tools and materials faced, the surrounding environment in which a person works, his work methods, and his work arrangements either as individuals or as a group [16]. Work environment as a whole work infrastructure around employees who are carrying out work that can affect the implementation of the work itself [15]. The work environment is everything that is around the workers which can influence him/her in carrying out the assigned duties [11]. The work environment is the entire tooling and materials faced, the environment around which a person works, his work methods and work arrangements both as individuals and as a group [16].

Based on the various opinions above, it can be concluded that the work environment is a condition in which employees work in a company which can affect the physical and psychological conditions of employees both directly and indirectly so that the work environment can be said to be good if employees can work optimally, calmly and with productivity. high.

Broadly speaking, the type of work environment is divided into 2, namely the physical work environment and the nonphysical work environment [16]. Physical support is all physical conditions that exist around the workplace that can affect employees either directly or indirectly. Included in the physical work environment are:

1. An environment that is directly related to employees. Such as chairs, tables, and so on,

2. The general environment is the work environment that affects human conditions, for example temperature, humidity, air circulation, lighting, noise, vibration, unpleasant odors, colors, and others.

\section{Work Performance}

Employee performance is the entire work process of an individual whose results can be used as a basis for determining whether the individual's work is good or vice versa [24]. Performance is the output produced by functions or indicators of a job or a profession within a certain time [22]. Based on some of the opinions above, it can be concluded that employee performance is the work result of an employee as long as he works in carrying out the main duties of his position which can be used as a basis for whether the employee can be said to have good performance or vice versa. A person's job performance can be measured by:

1. Work quality, in this case is related to timeliness, skills and personality in doing work,

2. Quality of work is related to the provision of additional tasks given by superiors to subordinates, such as working overtime,

3. Resilience, related to the level of attendance in giving time off and 
The Influence of Leadership, Motivation, and Working Environment on Employee Performance in Agriculture Department of Boalemo District, Gorontalo Province

schedules for late attendance at work,

4. Attitude, is the attitude that exists in employees that shows how far their attitudes and responsibilities are towards their peers and superiors and how far the level of cooperation is in evaluating assignments [17].

The objectives of performance appraisal are as follows:

1. Administration, which provides directions for determining promotions, transfers and salary increases.

2. Information, namely providing data to management about subordinate work performance and providing data to individuals about their strengths and weaknesses.

3. Motivation, namely creating learning experiences that motivate staff to develop themselves and improve their performance [14].

\section{RESEARCH METHODS}

This study used a survey method and analyzed quantitatively. To test the researcher's hypothesis about the existence of a positive and significant influence between leadership, motivation, and work environment on employee performance, the researchers developed a number of statements and answer choices in the form of a questionnaire distributed to 50 employees of the Boalemo Regency Agriculture Service. With indicators for each variable.

\section{RESEARCH RESULT \\ Multiple Regression Test Results}

Multiple linear regression is used to determine how much influence the dependent variable has on the dependent variable. Based on the calculation of multiple linear regressions between leadership (X1), Motivation (X2), and Work Environment (X3) on Employee Performance (Y) with the help of the SPSS17 program in the calculation process can be seen in the following table:
Table 1: Multiple Linear Regression Analysis Test Results

\begin{tabular}{|c|c|c|c|c|}
\hline & 1standardized & Standardized & Coeffici & ents \\
\hline \multicolumn{5}{|c|}{ Model } \\
\hline \multirow[t]{4}{*}{1} & (Constant) & 2,763 & 1,349 & \\
\hline & Leadership & 255 & .121 & 259 \\
\hline & Motivation & .791 & .118 & .799 \\
\hline & Work environment & -170 & .075 & -164 \\
\hline & endent & Variable: & & mpl \\
\hline
\end{tabular}

Source: 2017 Data Analysis Results

The table above shows the results of regression data processing between leadership (X1), motivation (X2), and work environment (X3), on employee performance $(Y)$. the results of the multiple linear regression equation from this research model are:

$\mathrm{Y}=2.763+0.255 \mathrm{x} 1+0.791 \times 2-0.170 \times 3$

Based on the results of the multiple linear regression equation above, it can be described as follows:

The Y constant of 2,763 states that if the variables of leadership (X1), motivation (X2), and work environment (X3) do not exist, then the employee performance is still 2,763 units.

The X1 coefficient of 0.255 shows that the leadership variable (X1) has a positive effect on employee perfor-mance, or in other words, if the leader assigns tasks/jobs in accordance with the potential and abilities of employ-yees, it can improve the quality of the employee's work. So that the perfor-mance of employees at the Boalemo Regency Agriculture Office, Gorontalo Province will increase by 25.5 percent.

The $\mathrm{X} 2$ coefficient of 0.791 shows that the motivation variable (X2) has a positive effect on employee perfor-mance or in other words that employ-yees who have a desire to be more successful than others will complete their work in accordance with the established procedures. So that the performance of the Boalemo District Agriculture Office staff in Gorontalo Province will increase by 79.1 percent. 
The Influence of Leadership, Motivation, and Working Environment on Employee Performance in Agriculture Department of Boalemo District, Gorontalo Province

The X3 coefficient of -0.170 shows that the work environment variable (X3) has a negative and insignificant effect on employee performance, or in other words the unclean and hot workspace conditions will cause employees to be uneasy and lack enthusiasm in completing their work, so that employyee performance. The Agriculture Office of Boalemo Regency, Gorontalo Province, will decline by 1.70 percent.

T-test is used to determine how far the independent variables (leadership, motivation and work environment) influence individually/partially on the dependent variable (employee performance). The results of the t-test can be seen in the following table:

Table 2: Hypothesis Testing Results with T-Test

\begin{tabular}{cccccc}
\hline \multirow{2}{*}{ Model } & $\begin{array}{c}\text { Unstandardized } \\
\text { Coefficients }\end{array}$ & $\begin{array}{c}\text { Standardized } \\
\text { Coefficients }\end{array}$ & \\
\cline { 2 - 6 } & B & Std. Error & Beta & t & Sig. \\
\hline (Constant) & 2,763 & 1,349 & & 2,048 & .046 \\
\hline Leadership & .255 & .121 & .259 & 2,100 & .041 \\
\hline Motivation & .791 & .118 & .799 & 6,678 & .000 \\
\hline $\begin{array}{c}\text { Work } \\
\text { environment }\end{array}$ & -170 & .075 & -164 & $-2,268$ & .028 \\
\hline
\end{tabular}

Source: 2017 Data Processed Results

The table above shows the $t$ value from the results of the SPSS calculation for each variable, namely the employee performance variable obtained a $t$ value of 2.048 , the leadership variable obtained a $t$ value of 2.100 , the motivation variable obtained a $t$ value of 6,678 and the work environment variable obtained a $\mathrm{t}$ value. count $-2,268$.

To determine whether there is an effect between each independent variable and the dependent variable, hypothesis testing is carried out with the following steps:

a. Determine the formulation of the hypothesis

HO: bi $=0$, meaning that there is no influence between variables $\mathrm{X} 1, \mathrm{X} 2$, $\mathrm{X} 3$, on variable $\mathrm{Y}$.

$\mathrm{H} 0$ : bi $<0$, meaning that there is a negative influence between variables
$\mathrm{X} 1, \mathrm{X} 2, \mathrm{X} 3$ on variable $\mathrm{Y}$.

$\mathrm{H} 0$ : bi $>0$, meaning there is negative influence between variables X1, X2, X3 to variable $\mathrm{Y}$.

b. Determine the level of significance; Significance level $(\alpha)=0.05$, then $\mathrm{t}$ table $(\mathrm{nk})=\mathrm{t}(50-4)$. For calculations I use EXCEL with the formula = tinv $(0.05 .46)$ the result is 2.013 .

c. The $t$ value from the SPSS calculation results obtained by the $t$ count for each variable $\mathrm{X}$ is:

$\mathrm{X} 1=2,100$

$\mathrm{X} 2=6,678 \mathrm{X} 3=-2,268$

d. Decision

Ho is accepted and $\mathrm{Ha}$ is rejected if $\mathrm{t}$ count $<t$ table

$\mathrm{Ha}$ is accepted and Ho is rejected if $\mathrm{t}$ count $>t$ table

From the results of the t-test analysis for leadership variables on employee performance, it is found that $\mathrm{t}$ counts $2.100>t$ table 2.2012 and a significant value of $t \quad 0.041<0.05$ indicates that leadership (X1) has a positive and significant effect on employee performance (Y). So Ha was accepted and Ho was rejected

From the results of the t-test analysis for the motivation variable on employee performance, it is found that $t$ counts $6,678>t$ table 2,013 and a significant value of $t 0,000<0.05$ indicates that motivation (X2) has a positive and significant effect on employee performance (Y). So Ho was rejected and Ha accepted.

From the results of t-test analysis for work environment variables on employee performance, it is found that $t$ count -2.268 $<\mathrm{t}$ table 2.013 and a significant value $\mathrm{t}$ $0.028<0.05$ indicates that the work environment (X3) has a negative and significant effect on employee performance (Y). So Ho was accepted and Ha was rejected.

The coefficient of determination (R2) is used to determine the percentage of 
The Influence of Leadership, Motivation, and Working Environment on Employee Performance in Agriculture Department of Boalemo District, Gorontalo Province

independent variables (leadership, motivation, and work environment) that together can explain the dependent variable (employee performance). The results of the coefficient of determination can be seen in the following table:

Table 3: Test Results The coefficient of determination (R2)

Model Summary,

\begin{tabular}{ccccc}
\hline \multirow{2}{*}{ Model } & \multirow{2}{*}{$\begin{array}{c}\text { Adjuste 1. Error of } \\
\end{array}$} & & $\mathrm{R}$ & \multicolumn{2}{c}{$\mathrm{d}$ R } & the \\
& Square & Square & Estimate \\
\hline 1 & $.934 \mathrm{a}$ & .873 & .865 & .689 \\
\hline
\end{tabular}

a. Predictors: (Constant), Work

Environment, Motivation, Leadership

The table above shows the value of Adjusted R Square or the coefficient of determination (R2) of 0.865 . This shows the magnitude of the influence of the variables of leadership, motivation and work environment on the performance of the staff of the Boalemo Regency Agriculture Office, Gorontalo Province, amounting to 86.5 percent, while the remaining 13.5 percent is influenced by variables not studied. From the results of $\mathrm{R}$ Square, it shows that leadership, motivation and work environment have a big influence in shaping the performance achievements of the employees of the Boalemo Regency Agriculture Office, Gorontalo Province.

\section{CONCLUSION}

From the results of the research and discussion above, it can be concluded as follows:

1. Leadership has a significant effect on employee performance so that if leadership in the Boalemo District Agriculture Office, Gorontalo Province can be carried out effectively, it will be followed by increasing employee performance.

2. Motivation has a significant effect on employee performance so that efforts to increase employee motivation properly will be followed by increased performance in the Boalemo Regency Agriculture Office, Gorontalo Province.

3. The work environment has a negative and significant effect on employee performance, in the sense that an unsanitary work environment and hot workspace conditions will cause employees to be uneasy and lack enthusiasm in completing their work, resulting in decreased employee performance at the Boalemo Provincial Agriculture Office. Gorontalo.

\section{REFERENCES}

[1] Dharma, Surya. 2009. Manajemen Kinerja Falsafah Teori Dan Penerapannya. Yogyakarta: Pustaka Pelajar.

[2] Fahmi, Irham. 2013. Manajemen Teori, Kasus dan Solusi. Bandung: Alfabeta.

[3] Gibson. 2008. Manajemen Sumber Daya Manusia, Edisi Keempat. Jakarta: Erlangga

[4] Hariandja, Marihot Tua Efendi. 2007. Manajemen Sumber Daya Manusia. Jakarta: Grasindo.

[5] Hasibuan, Malayu S.P. 2007, Manajemen Dasar, Pengertian, dan. Masalah,Edisi Revisi. Jakarta: Bumi Aksara.

[6] Hasibuan, Malayu S. P. 2011. Manajemen Sumber Daya Manusia. Jakarta: PT. Bumi Aksara.

[7] Kartono, Kartini. 2009. Pemimpin dan kepemimpinan. Apakah Kepemimpinan Abnormal Itu? Jakarta: Rajawali Pers.

[8] Kuswandi. 2004. Cara Mengukur KepuasanKerja. Jakarta: Elex Media Komputindo.

[9] Luthans, Fred. 2006. Perilaku Organisasi. Edisi Indonesia. Yogyakarta: ANDI.

[10] Mangkunegara, A. A. Anwar Prabu. 2012. Evaluasi Kinerja SDM. Bandung:Reflika Aditama. 
The Influence of Leadership, Motivation, and Working Environment on Employee Performance in Agriculture Department of Boalemo District, Gorontalo Province

[11] Nitiseminoto, Alex S. 2001. Manajemen Sumber Daya Manusia. Cetakan ke Sembilan, Edisi ke Tiga. Jakarta: Ghalia Indonesia.

[12] Purwanto, 2008. Unsur Motivasi. Jakarta: Balai Pustaka.

[13] Reksohadiprojo, S. dan Handoko, T.H. 2006. Organisasi Perusahaan: Teori, Struktur dan Perilaku. Edisi 2. Yogyakarta: BPFE

[14] Samsuddin, Sadili. 2006. Manajemen Sumber Daya Manusia. Cetakan ke 1. Bandung: Pustaka Setia.

[15] Saydam, Gouzali. 2000. Manajemen Sumber Daya Manusia (Human Resource) Suatu Pendekatan Mikro. Jakarta: Djanbatan

[16] Sedarmayanti. 2009. Sumber Daya Manusia. Cetakan pertama. Bandung: PT. Refika Aditama.

[17] Sunyoto, Danang. 2013. Manajemen Sumber Daya Manusia. Yogyakarta: CAPS (Center for Academic Publishing Service).

[18] Suwatno, Donni dan Juni Priansah.
2011. Manajemen SDM dalam Organisasi Publik dan Bisnis. Bandung: Alfabeta.

[19] Terry, George. R. 2013. Prinsipprinsip Manajemen. Penerjemah Smith.Jakarta: PT. Bumi Aksara.

[20] Thoha, Miftah. 2010. Kepemimpinan Dan Manajemen, Devisi Buku Perguruan Tinggi. Jakarta: PT. Raja Grafindo Persada.

[21] Tjiptono, Fandy. 2006. Manajemen Jasa. Edisi Pertama. Yogyakarta: Andi Gerry Ramadhan.

[22] Wirawan. 2009. Evaluasi Kinerja Manajemn Sumberd Daya Manusia. Jakarta: Salemba Empat.

[23] Yahya, S., Mashudi, I., \& Podungge, D. (2020). Mapping Analysis of Characteristics and Leadership Skills of Private Universities in Gorontalo City in the Era 4.0. Journal La Sociale, 1(4), 33-37.

[24] Zainur, Roziqin Muhammad. 2010. Kepuasan Kerja. Malang: Averroes Press. 